\title{
Human leukocyte antigen-G expression and polymorphisms promote cancer development and guide cancer diagnosis/treatment (Review)
}

\author{
YANWEN ZHANG ${ }^{1,2}$, SHUWEN YU $^{3}$, YALI HAN ${ }^{2}$, YUNSHAN WANG $^{4}$ and YUPING SUN ${ }^{2}$ \\ ${ }^{1}$ Department of Oncology, School of Medicine, Shandong University, Jinan, Shandong 250012; \\ Departments of ${ }^{2}$ Oncology and ${ }^{3}$ Pharmacy; ${ }^{4}$ Medical Research and Laboratory Diagnostic Center, \\ Jinan Central Hospital Affiliated to Shandong University, Jinan, Shandong 250013, P.R. China
}

Received December 10, 2015; Accepted June 2, 2017

DOI: 10.3892/ol.2017.7407

\begin{abstract}
Human leukocyte antigen-G (HLA-G) is a non-classical HLA molecule, predominantly expressed in cytotrophoblast cells to protect the fetus during pregnancy. Notably, a high frequency of HLA-G expression has been observed in a wide variety of cancer types in previous studies. Furthermore, HLA-G expression in cancer has been considered to be detrimental, since it can protect cancer cells from natural killer cell cytotoxic $\mathrm{T}$ lymphocyte-mediated destruction, promote tumor spreading and shorten the survival time of patients by facilitating tumor immune evasion. In addition, HLA-G polymorphisms have been investigated in numerous types of cancer and are considered as risk factors and predictive markers of cancer. This review focuses on HLA-G expression and its polymorphisms in cancer, analyzing the mechanisms of HLA-G in promoting cancer development, and evaluating the potential and value of its clinical application as a diagnostic and prognostic biomarker, or even as a prospective therapeutic target in certain types of tumors.
\end{abstract}

\section{Contents}

1. Introduction

2. Structure and physiology of HLA-G

Correspondence to: Professor Yunshan Wang, Medical Research and Laboratory Diagnostic Center, Jinan Central Hospital Affiliated to Shandong University, 105 Jie Fang Road, Jinan, Shandong 250013, P.R. China

E-mail: sdjnwys@163.com

Professor Yuping Sun, Department of Oncology, Jinan Central Hospital Affiliated to Shandong University, 105 Jie Fang Road, Jinan, Shandong 250013, P.R. China

E-mail: 13370582181@163.com

Key words: human leukocyte antigen-G, cancer, genetic polymorphism, immune evasion, tumor development, therapeutic target
3. HLA-G expression and plasma sHLA-G levels in cancer and their association with clinical parameters

4. HLA-G polymorphisms promote cancer development

5. HLA-G is involved in cancer development

6. Role of HLA-G in the diagnosis of cancer

7. HLA-G as a potential therapeutic target in cancer

8. Conclusion

\section{Introduction}

Human leukocyte antigen-G (HLA-G), a non-classical major histocompatibility complex class I (MHC-I) antigen, has well-recognized tolerogenic properties (1). HLA-G has been detected under physiological conditions in fetal tissues, adult immune-privileged organs and cells of the hematopoietic lineage (1), as well as under pathological conditions in cancer, viral infections, inflammatory diseases, autoimmune diseases and transplantation (2).

HLA-G was first detected at the maternal-fetal interface in the trophoblast, possibly performing a role in the modulation of the maternal immune system during pregnancy (3). The expression of HLA-G in fetal tissue successfully suppressed the local immune response in the placenta, therefore inducing maternal-fetal tolerance, preventing the fetus from being recognized as a non-self tissue and protecting it from lysis mediated by natural killer (NK) cells (4). Similarly, HLA-G expression in tumors can also protect cancer cells from NK cell and cytotoxic T lymphocyte (CTL)-mediated destruction (5). In this context, HLA-G expression may be a mechanism used by cancer cells to escape host immune surveillance.

Differing from classical HLA, the HLA-G gene presents limited coding region variability (6). Variation at the $5^{\prime}$ upstream regulatory region (5'URR) and 3' untranslated region (3'UTR) has been observed most frequently (6). Several lines of evidence have indicated that HLA-G polymorphisms affect the expression level of HLA-G, the production of different isoforms and the pattern of alternative splicing $(7,8)$. Polymorphisms in HLA-G have been studied in pathophysiological conditions, revealing that HLA-G polymorphisms are associated with 
numerous types of disorders, including pre-eclampsia (9), recurrent spontaneous abortion (10), asthma (11), systemic lupus erythematosus (12) and pemphigus vulgaris (13). In addition, several isolated segments of the HLA-G gene have been studied in different tumor types and were identified to be associated with tumor progression (14).

The present review discusses HLA-G expression and its gene polymorphisms in tumors, and analyzes its underlying mechanisms in promoting tumor development. Furthermore, the possible clinical applications of HLA-G (or sHLA-G) as a diagnostic and prognostic biomarker for cancer, and as a potential therapeutic target for cancer biotherapy are considered.

\section{Structure and physiology of HLA-G}

HLA-G is a MHC-I antigen encoded by a gene on chromosome 6 at region $6 \mathrm{p} 21.3$ (15). It has been termed as a non-classical HLA class I molecule, since it differs from classical HLA class I molecules due to its unique promoter region, limited polymorphism, restricted tissue distribution and immunosuppressive function (16). The structure of HLA-G is different to HLA class I (17). The main difference resides in the presence of a stop codon in exon 6 , which generates a shorter HLA-G protein compared with the classical HLA-G class I molecule (17). Compared with the high incidence of polymorphism in classical HLA class I molecules, HLA-G exhibits limited genetic polymorphism with only 50 alleles, which are distributed within the $\alpha 1, \alpha 2$ and $\alpha 3$ domains (15). HLA-G consists of seven isoforms, including four membrane-bound isoforms (HLA-G1-HLA-G4) and three secreted isoforms (sHLA-G; HLA-G5-HLA-G7), which are generated by alternate splicing of primary transcripts (18). sHLA-Gs contain an intron 4-encoded stop codon, resulting in the lack of transmembrane domain (19). Membrane-bound HLA-G1 and its soluble counterpart, HLA-G5 have been most studied in tissues or cells of organisms (1). In addition, sHLA-G molecules may also be shed via the proteolytic cleavage of membrane-bound HLA-G1 (20). Therefore, sHLA-G consists of sHLA-G1 and HLA-G5, of which HLA-G5 is the primary component (20). HLA-G1 and HLA-G5 are composed of heavy chains consisting of three globular domains $(\alpha 1, \alpha 2$, $\alpha 3$ ), which non-covalently bind to $\beta 2$-microglobulin $(\beta 2-\mathrm{m})$, and a nonapeptide, while the other isoforms lacking one or two globular domains can bind neither $\beta 2-\mathrm{m}$ nor present peptides (21).

In healthy individuals, HLA-G was first detected in extra-villous cytotrophoblast at the maternal-fetal interface, being regarded as a molecule that modulates the maternal immune system during pregnancy (3). It is also expressed by amnion epithelial cells, endothelial cells of fetal blood vessels in the placenta, erythroblasts, macrophages, antigen-presenting cells and dendritic cells (DCs), as well as by immune-privileged organs of adults, including the thymus, cornea and pancreatic islets (22). Additionally, ectopic HLA-G expression can be induced in various pathological conditions, including cancer, viral infections, inflammatory diseases, viral infections, autoimmune diseases and transplantation (1)

Considered as immunomodulatory molecules, HLA-G antigens can induce immunological tolerance by inhibiting certain immune-competent cells (22). The immune-suppressive function of HLA-G antigens may be mediated by binding membrane-bound and sHLA-G to their specific inhibitory receptors (23). Regarding these receptors, HLA-G antigens preferentially act as ligands for immunoglobulin-like transcript 2 (ILT2) and immunoglobulin-like transcript 4 (ILT4) (23). ILT2 is expressed by B cells/T cells/NK cells/monocytes/DCs, and ILT4 is presented on monocytes/macrophages/DCs $(24,25)$. In addition, HLA-G antigens were also reported to be ligands for the killer cell immunoglobulin-like receptor [KIR2DL4/p49 (CD158d)], which is expressed on NK cells (26). The direct interactions between HLA-G proteins and their specific inhibitory receptors promote the maintenance of tolerance at different stages of the immune response, consisting of differentiation, proliferation, cytolysis and cytokine secretion (27). It was also demonstrated that HLA-G could modulate the differentiation of DCs by interacting with ILT4, which requires the interleukin (IL)-6-signal transducer and activator of transcription 3 (STAT3) signaling pathway and results in the recruitment of Src homology region 2 domain-containing phosphatase (SHP)-1 and SHP-2 protein tyrosine phosphatases (28). Furthermore, the cell cycle of human-activated $T$ cells can be suppressed by activating SHP-2 phosphatase and inhibiting the mechanistic target of rapamycin pathway mediated by HLA-G (29). Notably, HLA-G may upregulate the inhibitory receptors in immune cells, which may precede an immune response and be involved in immune escape mechanisms by increasing their activation thresholds (30).

In addition to these direct effects, HLA-G can implement its indirect immune-inhibitory function through the expression of non-classical HLA class I molecule HLA-E $(16,31)$. HLA-E can directly bind the peptides derived from HLA-G, and the HLA-E/peptide complexes can interact with the inhibitory receptor CD94/NKG2A, which is predominantly expressed on NK cells (31). Thus, the effect of HLA-E on immune cells is of great importance for the inhibition of NK and T cell reactivity (31). Indeed, HLA-G-mediated immune tolerance may be extended to induce regulatory $\mathrm{T}$ cells $\left(\mathrm{T}_{\text {regs }}\right)$, a subpopulation of $\mathrm{T}$ cells possessing abilities to modulate the immune system, abrogate the autoimmune reaction and maintain the tolerance-to-self antigens (32). For instance, in the presence of HLA-G, $\mathrm{CD}^{+}{ }^{+}$and $\mathrm{CD}^{+} \mathrm{T}$ cells may lose their capability to respond to antigenic stimulation and be differentiated into $\mathrm{T}_{\text {regs }}(32)$.

\section{HLA-G expression and plasma SHLA-G levels in cancer and their association with clinical parameters}

Since the ectopic expression of HLA-G in tumor cells was first described in melanoma by Paul et al (5) in 1998, a high frequency of HLA-G expression and plasma sHLA-G levels have been observed successively in different solid tumor types, as well as in hematological malignancies, including melanoma $(33,34)$, breast cancer $(35-44)$, lung cancer $(45-49)$, hepatocellular carcinoma (50-53), colorectal cancer (49,54-58), gastric cancer (49,59-61), esophageal carcinoma (49,62-65), nasopharyngeal carcinoma (66), laryngeal lesions (67), bladder transitional cell carcinoma (68), renal cell carcinoma (69-72), cervical cancer (73), thyroid carcinoma (74,75), 
Table I. HLA-G expression in different cancer types.

\begin{tabular}{|c|c|c|c|c|c|}
\hline Tumor type & Method & Total number & HLA-G ${ }^{+}$number & $\mathrm{HLA}^{-\mathrm{G}^{+}, \%}$ & (Refs.) \\
\hline Melanoma & IHC & 79 & 22 & 28.0 & $(33)$ \\
\hline \multirow[t]{8}{*}{ Breast cancer } & $\mathrm{IHC}$ & 52 & 31 & 59.6 & $(35)$ \\
\hline & $\mathrm{IHC}$ & 38 & 22 & 58.0 & $(36)$ \\
\hline & $\mathrm{IHC}$ & 36 & 14 & 36.0 & $(37)$ \\
\hline & IHC & 58 & 41 & 70.7 & $(38)$ \\
\hline & IHC & 235 & 155 & 66.0 & $(39)$ \\
\hline & $\mathrm{IHC}$ & 667 & 400 & 60.0 & $(40)$ \\
\hline & $\mathrm{IHC}$ & 45 & 28 & 62.0 & (41) \\
\hline & $\mathrm{IHC}$ & 45 & 29 & 64.4 & $(42)$ \\
\hline \multirow[t]{3}{*}{ Lung cancer } & IHC & 34 & 9 & 26.0 & $(45)$ \\
\hline & $\mathrm{IHC}$ & 106 & 79 & 75.0 & $(46)$ \\
\hline & $\mathrm{IHC}$ & 101 & 42 & 41.6 & (47) \\
\hline \multirow[t]{3}{*}{ Hepatocellular carcinoma } & $\mathrm{IHC}$ & 173 & 99 & 57.0 & $(50)$ \\
\hline & $\mathrm{IHC}$ & 219 & 110 & 50.2 & $(51)$ \\
\hline & WB & 36 & 24 & 66.7 & $(52)$ \\
\hline \multirow[t]{4}{*}{ Colorectal cancer } & RT-PCR & 39 & 34 & 87.0 & (54) \\
\hline & IHC & 201 & 130 & 64.6 & $(55)$ \\
\hline & $\mathrm{IHC}$ & 251 & 51 & 20.3 & $(56)$ \\
\hline & $\mathrm{IHC}$ & 102 & 72 & 70.6 & (57) \\
\hline \multirow[t]{3}{*}{ Gastric cancer } & $\mathrm{IHC}$ & 160 & 113 & 71.0 & $(59)$ \\
\hline & $\mathrm{IHC}$ & 179 & 89 & 49.7 & $(60)$ \\
\hline & IHC & 52 & 16 & 31.0 & (61) \\
\hline \multirow[t]{4}{*}{ Esophageal carcinoma } & IHC & 121 & 110 & 90.9 & $(62)$ \\
\hline & $\mathrm{IHC}$ & 79 & 52 & 65.8 & (63) \\
\hline & $\mathrm{IHC}$ & 60 & 40 & 75.0 & (64) \\
\hline & $\mathrm{IHC}$ & 60 & 42 & 70.0 & $(65)$ \\
\hline Nasopharyngeal carcinoma & $\mathrm{IHC}$ & 552 & 437 & 79.2 & (66) \\
\hline Laryngeal lesions & $\mathrm{IHC}$ & 109 & l & l & $(67)$ \\
\hline Bladder TCC & $\mathrm{IHC}$ & 75 & 51 & 68.0 & $(68)$ \\
\hline \multirow[t]{2}{*}{ Renal cell carcinoma } & $\mathrm{IHC}$ & 18 & 11 & 61.0 & $(69)$ \\
\hline & $\mathrm{IHC}$ & 38 & 29 & 76.0 & $(70)$ \\
\hline \multirow[t]{2}{*}{ Clear cell renal carcinoma } & $\mathrm{IHC}$ & 12 & 7 & 58.0 & $(71)$ \\
\hline & $\mathrm{IHC}$ & 95 & 47 & 49.5 & $(72)$ \\
\hline Cervical lesions & $\mathrm{IHC}$ & 129 & 81 & 62.8 & $(73)$ \\
\hline \multirow[t]{2}{*}{ PT } & IHC & 70 & 30 & 44.3 & (74) \\
\hline & IHC & 72 & 56 & 77.8 & $(75)$ \\
\hline FTC & IHC & 19 & 17 & 90.0 & (75) \\
\hline \multirow[t]{2}{*}{ Neuroblastoma } & $\mathrm{IHC}$ & 12 & 0 & 0.0 & (76) \\
\hline & $\mathrm{FC}$ & 9 & 9 & 100.0 & (77) \\
\hline \multirow[t]{4}{*}{ Glioblastoma } & IHC & 5 & 4 & 80.0 & (78) \\
\hline & IHC & 26 & 15 & 58.0 & (79) \\
\hline & $\mathrm{IHC}$ & 39 & 25 & 64.0 & $(80)$ \\
\hline & IHC & 108 & 65 & 60.2 & (81) \\
\hline
\end{tabular}

HLA-G, human leukocyte antigen-G; IHC, immunohistochemistry; WB, western blot analysis; RT-PCR, reverse transcription-polymerase chain reaction; FC, flow cytometry; TCC, transitional cell carcinoma of the human bladder; PTC, papillary thyroid cancer; FTC, follicular thyroid cancer.

neuroblastoma (76,77), glioblastoma (78-81) and myeloid leukemia (82). HLA-G expression in various cancer types is listed in Table I, and data regarding plasma sHLA-G levels detected by ELISA are presented in Table II. As shown in 
Table II. Plasma sHLA-G level detected by ELISA.

\begin{tabular}{|c|c|c|c|}
\hline Tumor type & $\begin{array}{l}\text { Number } \\
(\alpha / \beta)^{\mathrm{a}}\end{array}$ & $\begin{array}{l}\text { sHLA-G concentrate } \\
\left(\alpha^{\prime} \text { vs. } \beta^{\prime}\right)^{\mathrm{b}}\end{array}$ & (Refs.) \\
\hline Melanoma & $190 / 126$ & $41.95 \pm 2.15$ vs. $22.92 \pm 1.51 \mathrm{ng} / \mathrm{ml}^{\mathrm{c}}$ & (34) \\
\hline \multirow[t]{6}{*}{ Breast cancer } & $80 / 80$ & 117.2 vs. $10.1 \mathrm{U} / \mathrm{ml}^{\mathrm{d}}$ & (43) \\
\hline & $120 / 40$ & 70.59 vs. $46.05 \mathrm{U} / \mathrm{ml}^{\mathrm{d}}$ & (44) \\
\hline & $92 / 70$ & 82.19 vs. $9.65 \mathrm{U} / \mathrm{ml}^{\mathrm{d}}$ & $(38)$ \\
\hline & $44 / 48$ & 0.78 vs. $0.43 \mu \mathrm{g} / \mathrm{ml}^{\mathrm{c}}$ & (39) \\
\hline & $45 / 40$ & $35 \mathrm{vs} .7 .6 \mathrm{ng} / \mathrm{m}^{\mathrm{d}}$ & $(42)$ \\
\hline & $120 / 40$ & 70.59 vs. $46.05 \mathrm{U} / \mathrm{ml}^{\mathrm{d}}$ & (44) \\
\hline \multirow[t]{3}{*}{ Lung cancer } & $91 / 150$ & 32.0 vs. $20.4 \mathrm{U} / \mathrm{ml}^{\mathrm{d}}$ & $(47)$ \\
\hline & $137 / 84$ & $34 \mathrm{vs} .14 \mathrm{ng} / \mathrm{ml}^{\mathrm{d}}$ & $(48)$ \\
\hline & $43 / 120$ & 64 vs. $34 \mathrm{U} / \mathrm{ml}^{\mathrm{d}}$ & (49) \\
\hline Thyroid cancer & $183 / 245$ & 42.9 vs. $8.5 \mathrm{U} / \mathrm{ml}^{\mathrm{d}}$ & $(83)$ \\
\hline \multirow[t]{3}{*}{ Hepatocellular carcinoma } & $19 / 86$ & 92.49 vs. $9.29 \mathrm{U} / \mathrm{ml}^{\mathrm{d}}$ & $(51)$ \\
\hline & $36 / 25$ & $132.6 \mathrm{vs} .47 .0 \mathrm{U} / \mathrm{ml}^{\mathrm{d}}$ & $(52)$ \\
\hline & $80 / 50$ & 178.8 vs. $6.8 \mathrm{U} / \mathrm{ml}^{\mathrm{d}}$ & $(53)$ \\
\hline \multirow[t]{2}{*}{ Colorectal cancer } & $144 / 60$ & $124.3 \mathrm{vs} .25 \mathrm{U} / \mathrm{ml}^{\mathrm{d}}$ & $(58)$ \\
\hline & $37 / 129$ & $84 \mathrm{vs} .34 \mathrm{U} / \mathrm{ml}^{\mathrm{d}}$ & (49) \\
\hline \multirow[t]{2}{*}{ Gastric cancer } & $58 / 64$ & $130 \mathrm{vs} .38 \mathrm{U} / \mathrm{ml}^{\mathrm{d}}$ & $(60)$ \\
\hline & $28 / 120$ & 73 vs. $34 \mathrm{U} / \mathrm{ml}^{\mathrm{d}}$ & $(49)$ \\
\hline \multirow[t]{3}{*}{ Esophageal carcinoma } & $41 / 153$ & 152.4 vs. $8.9 \mathrm{U} / \mathrm{ml}^{\mathrm{d}}$ & $(63)$ \\
\hline & $58 / 120$ & 77 vs. $34 \mathrm{U} / \mathrm{ml}^{\mathrm{d}}$ & $(49)$ \\
\hline & $60 / 28$ & $15.04 \mathrm{vs} .6 .81 \mathrm{U} / \mathrm{ml}^{\mathrm{d}}$ & $(65)$ \\
\hline Bladder TCC & $15 / 105$ & 10.75 vs. $8.69 \mathrm{U} / \mathrm{ml}^{\mathrm{d}}$ & $(68)$ \\
\hline Clear cell renal carcinoma & $16 / 144$ & $39.5 \mathrm{vs} .19 .2 \mathrm{U} / \mathrm{ml}^{\mathrm{d}}$ & (72) \\
\hline Neuroblastoma & $53 / 53$ & $26.1 \pm 6.97$ vs. $4.409 \pm 0.808 \mathrm{ng} / \mathrm{ml}^{\mathrm{c}}$ & (76) \\
\hline AML & $47 / 37$ & $16.23 \pm 6.17$ vs. $52.8 \pm 32.7 \mathrm{ng} / \mathrm{ml}^{\mathrm{c}}$ & $(82)$ \\
\hline ALL & $28 / 37$ & 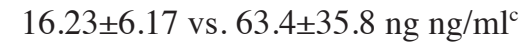 & $(82)$ \\
\hline
\end{tabular}

Table II, in the majority of cancer types, serum sHLA-G levels were significantly higher in patients with cancer compared with in the healthy controls. Notably, sHLA-G levels were similar between patients with bladder transitional cell carcinoma (TCC) and healthy controls (68).

However, the associations between increased HLA-G expression and the clinical parameters of patients with cancer remain conflicting. Although there was a significant association between increased HLA-G expression levels and certain clinical parameters, including advanced disease stage, poor histological grade, higher tumor grade, presence of metastasis, shorter survival time, greater tumor size, tumor recurrence or tumor invasion in many types of tumors (27), the association was not detected in other tumors, including bladder TCC (68) and acute myeloid leukemia (82). Although several studies have demonstrated that high serum sHLA-G levels were associated with aggressive behavior in cancer, histological type, tumor-node-metastasis stage or a shorter survival time of patients suffering from breast cancer, papillary thyroid carcinoma (PTC) and lung cancer among others, no clear associations were identified between the plasma sHLA-G levels and the clinicopathological parameters in colorectal cancer, hepatocellular carcinoma, esophageal carcinoma, renal cell carcinoma and gastric cancer $(38,43,45,83)$. Notably, numerous factors may affect sHLA-G expression $(65,82)$. The upregulated plasma IL-10 level in primary esophageal squamous cell carcinoma was determined to be associated with high sHLA-G levels (65). In addition, sHLA-G levels have been established as associated with the deficiency of anterior myelodysplasia along with higher leukocytosis in acute myeloid leukemia (82). Notably, contradictions exist in the same type of tumor between different studies. For instance, Kren et al (70) confirmed that HLA-G is upregulated in renal cell carcinoma tissues and that it is associated with a worse prognosis. By contrast, Reimers et al (84) reported that weak HLA-G expression was associated with a poor prognosis and a significantly worse survival. These contradictions may 
possibly be attributed to differing ethnicities in the patient cohorts, varied criteria of patient selection, the methods used and factitious surgical errors.

\section{HLA-G polymorphisms promote cancer development}

Compared with classical HLA, the HLA-G gene presents limited coding region variability (6). However, variations at the 5'URR and at the 3'UTR have been observed in numerous previous studies $(6,85-87)$. Recently, a number of studies indicated that HLA-G polymorphisms are associated with HLA-G expression (41), cancer susceptibility (88-91) and cancer development (86).

Although it remains a controversial issue as to where HLA-G transcription begins, the polymorphisms at the 5'URR and haplotypes at the 3'UTR are considered to affect HLA-G expression (7). In healthy Brazilian and French individuals, the 14-bp del/del genotype exhibited higher sHLA-G levels compared with the 14-bp ins/ins genotype (85). Additionally, in patients with invasive ductal carcinoma, 14-bp ins/del polymorphisms may induce a higher expression of the HLA-G molecule compared with 14-bp ins/ins and 14-bp del/del polymorphisms (41). The differential expression levels were attributed to the fact that polymorphic sites at the 5'URR coincided with the known transcription factor binding sites, and that the polymorphic sites at 3'UTR affect mRNA stability and the binding of specific microRNAs (85).

It has previously been demonstrated that $14-\mathrm{bp}$ polymorphisms may be a genetic risk factor for susceptibility to several types of cancer $(87,88,91)$. A study in Australia and New Zealand identified an association between heterozygote carriers of the HLA-G 14-bp ins/del polymorphism and decreased risk of neuroblastoma (88). Another study demonstrated that the 14-bp del allele may promote human papillomavirus infection and the 14-bp del/ $+3142 \mathrm{C}$ haplotype may be involved in invasive cervical cancer (ICC) development (91). In addition, in Brazilian patients who smoke, the polymorphic 14-bp ins/ins genotype and 14-bp ins/+3142 G haplotypes were associated with an increased risk of high-grade squamous intraepithelial lesion (HSIL) and a higher risk of developing ICC, while the 14-bp del/del genotype and 14-bp del/ $+3142 \mathrm{G}$ haplotypes were associated with a lower risk of HSIL and cervical cancer (86). By contrast, no significant differences in the +14/-14 bp polymorphism frequencies were observed between patients with PTC and the healthy control group. However, the association between 14-bp polymorphisms and cancer susceptibility is discrepant in distinct ethnic populations. The presence of the HLA-G 3'UTR 14-bp sequence was observed to be associated with a reduced risk of breast cancer susceptibility in HLA-G-expressing tissues in Southeastern Iranian (92) and Korean patients (43). However, the association between HLA-G 3'UTR 14-bp sequence and breast cancer susceptibility was not observed in Brazilian patients with breast cancer (93). In addition, the 14-bp del/del allele was revealed to increase hepatocellular carcinoma (HCC) susceptibility in Brazilian (94) and Chinese (87) patients, but the variation was not associated with HLA-G expression and susceptibility to HCC in Korean patients (95).

Other polymorphisms of HLA-G have also been investigated. In Canadian populations with cervical cancer, the homozygous genotype form of the HLA-G*01:01:02, - $G^{*} 01: 06$ and $-G^{*} 3^{\prime}$ UTR 14-bp insertions were identified to be associated with a significantly increased risk for invasive cancer, compared with the wild-type heterozygous form of the HLA-G*01:01:01 allele (89). Evaluating the effect of HLA-G polymorphism occurrence on nasopharyngeal carcinoma (NPC) susceptibility in Tunisian patients, researchers observed that the lle110 allele was associated with fewer lymph node metastases and an increased number of patients with higher tumor stages, and the occurrence of codon $130 \mathrm{C}$ deletion reduced the disease-free and overall survival rates of patients with NPC (90). To date, and to the best of our knowledge, HLA-G polymorphisms have not been investigated in a number of tumor types, including lung cancer, gastric cancer, colorectal cancer, melanoma, renal cell carcinoma and glioblastoma.

Therefore, HLA-G polymorphisms may be risk factors and predictive markers for several types of cancer. However, the conflicting results regarding the association between HLA-G polymorphisms and cancer susceptibility indicate that additional studies consisting of populations from different ethnicities and larger sample sizes are required.

\section{HLA-G is involved in cancer development}

Since HLA-G expression was observed in various types of cancer, the roles of HLA-G in promoting cancer progression were investigated in a number of studies (17,96-98). Studies revealed that HLA-G and sHLA-G have multiple mechanisms of involvement in the development of malignancies (Fig. 1).

Available evidence has demonstrated that HLA-G may be actively involved in the immune escape mechanism of tumor cells (17). Cancer immunoediting is an important host protection process (97). In this process, the immune surveillance can be divided into three essential steps, including an elimination phase, equilibrium phase and escape phase (97), and HLA-G is involved in each of these three phases (2). Several adaptive/innate immunizing molecules and cells are involved in inhibiting the elimination of tumor cells (98). As mentioned earlier, HLA-G could bind to its special receptors on immune effector cells, thereby blocking the proliferation and lytic function of uterine and peripheral NK cells in a physiological context (4). Similarly, sHLA-G released by cancer cells can bind to the receptors on NK cells and T cells, leading to the apoptosis of immune cells (Fig. 1A). HLA-G expression in tumors such as hepatocellular carcinoma, glioma, melanoma, renal, ovarian and lung carcinoma can also protect cancer cells from NK and CTL-mediated destruction $(99,100)$ (Fig. 1B). In addition, plasmatic sHLA-G molecules secreted by melanoma M8 cells functionally and potently inhibit NK cell cytotoxicity by weakening the lytic granules polarization toward the target cells (101). The formation of HLA-G and its soluble counterpart, HLA-G5, can be increased by numerous pro-inflammatory cytokines from the tumor microenvironment, including interferon (IFN)- $\beta$ and IFN- $\gamma$, which enhance the protection of tumor cells from NK cell-mediated cytolysis (62). HLA-G can affect the equilibrium phase by allowing cancer cell persistence, resulting in the selection of tumor cells with reduced immunogenicity (102). Tumor development primarily occurs in the evasion phase (103); in this phase, tumor cells tend to express only HLA-G on the cell surface, and not molecules essential to immune recognition, leading to the rapid growth of 


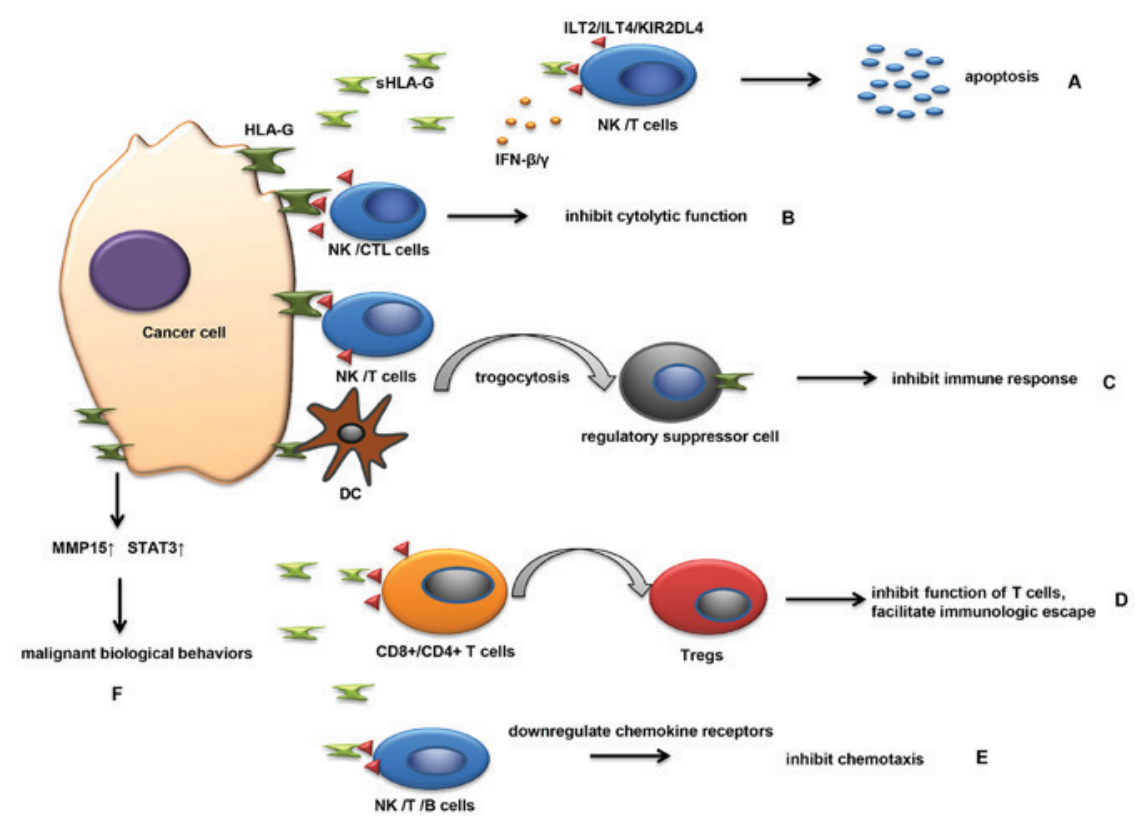

Figure 1. HLA-G and sHLA-G ae involved in the development of malignancies in multiple ways. (A) sHLA-G released by cancer cells binds to the receptors on NK cells and T cells, leading to the apoptosis of immune cells. (B) The interaction between HLA-G on cancer cells and its receptors on NK/CTL cells directly inhibit the function of activated immune cells. (C) During cell-cell contact, cancer cells transfer HLA-G-containing membrane patches to activated $\mathrm{NK} / \mathrm{DC} / \mathrm{T}$ cells. NK/DC/T cells that receive HLA-G temporarily behave as regulatory suppressor cells and acquire the ability to inhibit immune responses. (D) In the presence of sHLA-G, $\mathrm{CD} 4^{+}$and $\mathrm{CD} 8^{+} \mathrm{T}$ cells lose their capability to respond to antigenic stimulation and differentiate into $\mathrm{T}_{\text {regs }}$, which can inhibit T cell function and facilitate immunological escape. (E) sHLA-G can inhibit the chemokine receptors expressed on NK/T/B cells by interacting with ILT2 on cells. Losing the ability of chemotaxis, NK/T/B cells cannot migrate to pathological tissues and cannot regulate a series of immunological responses. (F) HLA-G may be involved in the invasiveness and metastasis of tumor progression by increasing the expression of MMPs and STAT3. HLA-G, human leukocyte antigen-G; sHLA-G, soluble HLA-G; NK, natural killer; CTL, cytotoxic T lymphocyte; DC, dendritic cell; MMP, matrix metalloproteinase; STAT3, signal transducer and activator of transcription 31 ILT2, immunoglobulin-like transcript 2; $\mathrm{T}_{\text {regs }}$, regulatory $\mathrm{T}$ cells; Ifn, interferon.

tumor cells and the creation of a hypoxic microenvironment. Furthermore, the hypoxic microenvironment and cytokines derived by tumor-like transforming growth factor- $\beta$ and IL-10 in this phase can upregulate HLA-G expression (104). Estrogenic G-protein-coupled estrogen receptor-1 signaling can trigger HLA-G expression by inhibiting miR148a in breast cancer cells (105). These mechanisms modulated by HLA-G are considered to facilitate the escape of tumor cells from the antigen-specific immune response and to create a microenvironment suitable for tumor cells (98).

Notably, HLA-G can be transferred from one HLA-G-expressing cell to another, a phenomenon defined as trogocytosis (106) (Fig. 1C). In this manner, cancer cells transfer HLA-G-containing membrane patches to activated NK cells (106). NK cells receiving the HLA-G temporarily behave as regulatory suppressor cells, and acquire the ability to inhibit immune responses such as prohibiting the proliferation of immune cells and inhibiting the cytotoxic effector of neighboring NK cells $(106,107)$. T cells and DCs may also possess regulatory properties subsequent to acquiring HLA-G antigens from malignant plasma cells, providing another novel mechanism for escaping effective immune surveillance (108). Similarly, the HLA-G-negative tumor cells in the vicinity of HLA-G-positive cells can be protected in this way (1). Therefore, this phenomenon may be an important mechanism underlying immune inhibition in physical conditions as well as in pathological conditions.

During tumor development, immune cells are able to infiltrate tumors and participate in tumor formation and progression $(22,98) . \mathrm{T}_{\text {regs }}$ are one type of tumor-infiltrating lymphocyte, which serve an important role in immunologic escape of tumor cells. High tumor-infiltrating $\mathrm{T}_{\text {regs }}$ are associated with the poor prognosis of human malignant tumors (98). $\mathrm{T}_{\text {regs }}$ can be induced by HLA-G not only under physiological conditions but also pathological conditions (22). Several studies have elucidated the association between HLA- $G$ and $\mathrm{T}_{\text {regs }}$ in malignant diseases $(38,60,61)$. It has been observed that the proportion of $\mathrm{CD} 4^{+} \mathrm{CD} 25^{+} \mathrm{FoxP} 3^{+} \mathrm{T}_{\text {regs }}$ was markedly increased in the plasma of breast cancer patients when compared with that in the plasma of healthy controls, and the increase was strongly associated with sHLA-G levels (38). In gastric cancer, a significant positive association between HLA-G expression and the presence of tumor-infiltrating $\mathrm{T}_{\text {regs }}$ was observed in tumor tissues (60). When gastric cancer cells were co-cultured with human peripheral blood mononuclear cells in vitro, HLA-G overexpression in gastric cancer cells significantly enhanced the number of $\mathrm{T}_{\text {regs }}(60)$. In addition, a negative correlation between HLA-G expression and the number of $\mathrm{CD}^{+} \mathrm{T}$ lymphocytes was observed in gastric tumor tissues using immunohistochemistry (61). This may be attributed to $\mathrm{CD}^{+} \mathrm{T}$ lymphocyte differentiation into $\mathrm{T}_{\text {regs }}$, induced by HLA-G (Fig. 1D). Taken together, these results indicate that HLA-G may be associated with tumor progression and may be involved in tumor evasion by inducing the production of $\mathrm{T}_{\text {regs }}$.

Another mechanism by which sHLA-G promotes cancer development is to inhibit the chemokine receptors expressed on NK/T/B cells (Fig. 1E), which can regulate the migration and recruitment of these cells by binding with chemotactic cytokines (109). Several studies have demonstrated that 
sHLA-G reduces the expression of CCR2/CXCR3/CXCR5 on $\mathrm{T}$ cells, downregulates CCR2/CXCR3/CX3CR1/CXCR5 expression on NK cells and inhibits CXCR4/CXCR5 expression on B cells by interacting with ILT2 (109-111). Following the loss of chemotaxic ability, NK/T/B cells cannot migrate to pathological tissues and consequently cannot regulate a series of immunological responses (109).

Furthermore, a previous study (96) determined that HLA-G may be involved in the invasion and metastasis stages of tumor progression (Fig. 1F). In ovarian carcinoma, HLA-G expression is closely associated with matrix metalloproteinase-15 (MMP-15) expression (100). Knockdown of MMP-15 expression significantly decreases the migration potential and tumor metastasis of HO-8910 ovarian serous cystadenocarcinoma cells (100). In JEG-3 gestational choriocarcinoma cells, downregulating HLA-G expression notably suppressed the activation of STAT3 and the invasion capacity of cancer cells (112). These data indicate that HLA-G may regulate the malignant biological behavior of cancer cells by affecting STAT3 activation and MMP-15 expression.

In addition, in vivo evidence of the immunosuppression function of HLA-G in tumors was provided by a number of studies. HLA-G may interact with the murine-paired immunoglobulin-like receptor-B, ortholog of human ILT receptors, enabling the role to be investigated in vivo (113). Agaugué et al (114) first established a HLA- $\mathrm{G}^{+}$xenotumor mouse model by subcutaneously injecting M8-HLA-G1 tumor cells into immunocompetent mice. This demonstrated that HLA-G serves a crucial role in immune evasion and promotes tumor expansion in vivo by depleting peripheral $\mathrm{T}$ cells and increasing blood myeloid-derived CD11b(+) Grl(+) PIR-B(+) suppressor cells (114). In another study, researchers injected syngeneic $\mathrm{h} \beta 2 \mathrm{~m}^{+} \mathrm{HLA}-\mathrm{G5}^{+}$tumor cells (tumor cells co-expressing HLA-G5 and human $\beta 2$-microglubulin) or $\mathrm{h} \beta 2 \mathrm{~m}^{+}$ HLA-G5- tumor cells into immunocompetent mice (115). The results indicated that secreted HLA-G5 protected $\mathrm{h} \beta 2 \mathrm{~m}^{+}$ HLA-G5 ${ }^{+}$tumor cells against immune rejection elicited by $\mathrm{h} \beta 2 \mathrm{~m}$, thereby permitting the immunogenic tumors to grow in a similar manner to poorly immunogenic tumors (115). These data highlight the crucial role of HLA-G in tumor immune surveillance and malignant disease progression.

\section{Role of HLA-G in the diagnosis of cancer}

As aforementioned, HLA-G expression levels in tumor tissue samples and high levels of sHLA-G in plasma samples, all obtained from patients with various types of cancer, have previously been detected, and high expression was determined to be significantly associated with high histological grade, lymph node metastasis, advanced clinical stage and a poor prognosis (96). Therefore, the application of HLA-G as a diagnostic and prognostic biomarker of cancer has been proposed.

Studies have demonstrated that HLA-G expression was higher in malignant lesions compared with that in benign hyperplasias $(73,75)$. In thyroid tissues, the percentage of cell staining for HLA-G antigen in PTC, follicular thyroid carcinomas and follicular adenomas (FA) was significantly higher than in colloid goiter and histologically normal thyroid glands (75). In cervical cancer lesions, HLA-G expression was increased in patients with invasive cervical cancer compared with that in patients with CIN III, and HLA-G expression was more frequently observed in cancer lesions from patients with a higher FIGO stage of cancer (73). In liver tissues, HLA-G expression was identified in the primary sites of HCC, but not detected in benign lesions represented by liver cirrhosis (LC) (52). ELISA assay also showed that the plasma sHLA-G level in patients with HCC was higher than in LC (52). These results indicated that HLA-G and sHLA-G may be involved in tumorigenesis and tumor development, which provides the basis for their purpose as indicators of early diagnosis.

HLA-G expression may also be a prognostic predictor of carcinoma following curative resection (50). For instance, high expression levels of HLA-G in hepatocellular carcinoma are independently associated with the shortening of overall survival times and an increase in tumor recurrence (50). In addition, patients with high HLA-G levels and a high $\mathrm{T}_{\text {regs }}: \mathrm{CD}^{+}$ratio exhibited $\geq 3$ times increased risk of tumor relapse and mortality, compared with those without (50). Therefore, the combination of HLA-G expression and the $\mathrm{T}_{\text {regs }}$ : $\mathrm{CD} 8^{+}$ratio served as an improved prognosticator (50). In colorectal cancer, patients with HLA-G expression in tissue have a significantly shorter survival time compared with those patients with HLA-G negative, indicating that HLA-G may be an independent prognostic factor for colorectal cancer (55).

In addition, HLA-G expression in tissues and sHLA-G concentrations in body fluids were useful for the prediction and diagnosis of cancer patients with various subtypes $(44,116)$. When sHLA-G plasma level was detected in 120 patients with breast cancer, Provatopoulou et al (44) found that sHLA-G levels were closely associated with histological type: sHLA-G expression in patients with mixed type co-existing ductal and lobular breast lesions was significantly higher than patients with pure ductal carcinoma or pure lobular neoplasia. Furthermore, the expression of HLA-G was significantly higher in non-luminal subtypes of invasive ductal breast carcinoma compared with in luminal subtypes (116).

Therefore, HLA-G/sHLA-G could be used as biomarkers to diagnose cancer in the early stages, to predict the prognosis of cancer patients and be used as subsidiary indicators to distinguish various cancer subtypes of cancer. Additionally, as aforementioned, HLA-G polymorphisms may be useful in the diagnosis of cancer.

\section{HLA-G as a potential therapeutic target in cancer}

In accordance with the important role of HLA-G in promoting tumor evolution and progression, targeting HLA-G has been deemed to be a novel innovative therapeutic strategy in cancer $(99,114)$. In human HCC cell lines, when HLA-G expression is diminished by applying the vectors containing small interfering RNA specifically targeting the HLA-G gene, a significant increase in NK cell-mediated lysis occurs, which prevents tumor progression (99). In xenotumor mouse models, blocking HLA-G using a specific antibody successfully inhibits the development of the tumor (114). Additional studies and clinical trials are required to demonstrate the value of HLA-G in targeted cancer therapy.

However, a noteworthy phenomenon to consider is that several therapeutics may induce HLA-G-negative tumors to express HLA-G, and thus contribute to cancer 
recurrence $(34,81)$. For example, a multicentric study has demonstrated that high expression levels of HLA-G in glioblastoma may be induced by combined 5-aza-2'-deoxycytidine and interferon- $\gamma$ treatments in vitro (81). Melanoma patients undergoing INF- $\alpha$ immunotherapy exhibited significantly enhanced increases in the serum sHLA-G level (34). Furthermore, it was demonstrated that HLA-G1 expression may modulate the radiosensitivity of human tumoral cell lines: HLA-G1 expressing cells had a higher radiosensitivity in human melanoma M8 and human erythroleukemia K562 cell lines (117). Thus, identification of HLA-G status may be conducive to improved selection of cancer patients who could benefit from more tailored immunological therapy or neoadjuvant biological therapy.

\section{Conclusion}

In conclusion, HLA-G is a potent immune-inhibitory molecule in healthy individuals and in pathological organisms. Although the frequency of HLA-G/sHLA-G expression and its association with clinical parameters varies between different cancer types, and even between different studies of the same tumor type, HLA-G expression in tumors has been considered to be detrimental. However, studies with a larger number of populations from different ethnicities are required.

Considering the ectopic expression of HLA-G and its gene polymorphisms in tumors, it is promising that membrane-bound and sHLA-G could be a potential diagnostic biomarker to identify tumors and to monitor disease stage. Since HLA-G has been demonstrated to be an important molecule in tumor immune escape and cancer development, blockade of HLA-G expression or elimination of HLA-G-expressing cancer cells may be important to the efficacy of anticancer therapies. Thus far, several molecular inhibitors have demonstrated their ability to specifically target the HLA-G gene; however, additional studies involving higher animals and clinical trials involving humans are required in order for these inhibitors targeting HLA-G to be used clinically.

\section{Acknowledgements}

The present study was financially supported by the National Natural Science Foundation of China (grant no. 81372334).

\section{References}

1. Carosella ED, Favier B, Rouas-Freiss N, Moreau P and Lemaoult J: Beyond the increasing complexity of the immunomodulatory HLA-G molecule. Blood 111: 4862-4870, 2008.

2. Amiot L, Ferrone S, Grosse-Wilde H and Seliger B: Biology of HLA-G in cancer: A candidate molecule for therapeutic intervention? Cell Mol Life Sci 68: 417-431, 2011.

3. Jiang F, Zhao H, Wang L, Guo X, Wang X, Yin G, Hu Y, Li Y and Yao Y: Role of HLA-G1 in trophoblast cell proliferation, adhesion and invasion. Biochem Biophys Res Commun 458: 154-160, 2015.

4. Rouas-Freiss N, Kirszenbaum M, Dausset J and Carosella ED: Fetomaternal tolerance: Role of HLA-G molecule in the protection of the fetus against maternal natural killer activity. C R Acad Sci III 320: 385-392, 1997 (In French).

5. Paul P, Rouas-Freiss N, Khalil-Daher I, Moreau P, Riteau B, Le Gal FA, Avril MF, Dausset J, Guillet JG and Carosella ED: HLA-G expression in melanoma: A way for tumor cells to escape from immunosurveillance. Proc Natl Acad Sci USA 95: 4510-4515, 1998.
6. Castelli EC, Mendes-Junior CT, Veiga-Castelli LC, Roger M, Moreau P and Donadi EA: A comprehensive study of polymorphic sites along the HLA-G gene: Implication for gene regulation and evolution. Mol Biol Evol 28: 3069-3086, 2011.

7. Rousseau P, Le Discorde M, Mouillot G, Marcou C, Carosella ED and Moreau P: The $14 \mathrm{bp}$ deletion-insertion polymorphism in the 3' UT region of the HLA-G gene influences HLA-G mRNA stability. Hum Immunol 64: 1005-1010, 2003.

8. Castelli EC, Mendes-Junior CT, Deghaide NH, de Albuquerque RS, Muniz YC, Simões RT, Carosella ED, Moreau P and Donadi EA: The genetic structure of 3'untranslated region of the HLA-G gene: Polymorphisms and haplotypes. Genes Immun 11: 134-141, 2010.

9. Hylenius S, Andersen AM, Melbye M and Hviid TV: Association between HLA-G genotype and risk of pre-eclampsia: A case-control study using family triads. Mol Hum Reprod 10: 237-246, 2004

10. Pandey MK, Rani R and Agrawal S: An update in recurrent spontaneous abortion. Arch Gynecol Obstet 272: 95-108, 2005.

11. Tahan F and Patiroglu T: Plasma soluble human leukocyte antigen $\mathrm{G}$ levels in asthmatic children. Int Arch Allergy Immunol 141: 213-216, 2006.

12. Consiglio CR, Veit TD, Monticielo OA, Mucenic T, Xavier RM, Brenol JC and Chies JA: Association of the HLA-G gene $+3142 \mathrm{C}>\mathrm{G}$ polymorphism with systemic lupus erythematosus. Tissue Antigens 77: 540-545, 2011.

13. Gazit E, Slomov Y, Goldberg I, Brenner S and Loewenthal R: HLA-G is associated with pemphigus vulgaris in Jewish patients. Hum Immunol 65: 39-46, 2004.

14. Dias FC, Castelli EC, Collares CV, Moreau P and Donadi EA: The Role of HLA-G molecule and HLA-G gene polymorphisms in tumors, viral hepatitis, and parasitic diseases. Front Immunol 6: 9, 2015.

15. Koller BH, Geraghty DE, DeMars R, Duvick L, Rich SS and Orr HT. Chromosomal organization of the human major histocompatibility complex class I gene family. J Exp Med 169: 469-480, 1989.

16. Morandi $F$ and Pistoia V: Interactions between HLA-G and HLA-E in Physiological and Pathological Conditions. Front Immunol 5: 394, 2014.

17. Carosella ED, Rouas-Freiss N, Tronik-Le Roux D, Moreau P and LeMaoult J: HLA-G: An immune checkpoint molecule. Adv Immunol 127: 33-1444, 2015.

18. Carosella ED, Moreau P, Le Maoult J, Le Discorde M, Dausset J and Rouas-Freiss N: HLA-G molecules: From maternal-fetal tolerance to tissue acceptance. Adv Immunol 81: 199-252, 2003.

19. Fujii T, Ishitani A and Geraghty DE: A soluble form of the HLA-G antigen is encoded by a messenger ribonucleic acid containing intron 4. J Immunol 153: 5516-5524, 1994.

20. Park GM, Lee S, Park B, Kim E, Shin J, Cho K and Ahn K: Soluble HLA-G generated by proteolytic shedding inhibits NK-mediated cell lysis. Biochem Biophys Res Commun 313: 606-611, 2004.

21. Ishitani A and Geraghty DE: Alternative splicing of HLA-G transcripts yields proteins with primary structures resembling both class I and class II antigens. Proc Natl Acad Sci USA 89: 3947-3951, 1992.

22. Curigliano G, Criscitiello C, Gelao L and Goldhirsch A: Molecular pathways: Human leukocyte antigen G (HLA-G). Clin Cancer Res 19: 5564-5571, 2013.

23. Gao GF, Willcox BE, Wyer JR, Boulter JM, O'Callaghan CA, Maenaka K, Stuart DI, Jones EY, Van Der Merwe PA, Bell JI and Jakobsen BK: Classical and nonclassical class I major histocompatibility complex molecules exhibit subtle conformational differences that affect binding to CD8alphaalpha. J Biol Chem 275: 15232-15238, 2000.

24. Colonna M, Samaridis J, Cella M, Angman L, Allen RL, O'Callaghan CA, Dunbar R, Ogg GS, Cerundolo V and Rolink A: Human myelomonocytic cells express an inhibitory receptor for classical and nonclassical MHC class I molecules. J Immunol 160: 3096-3100, 1998.

25. Borges L and Cosman D: LIRs/ILTs/MIRs, inhibitory and stimulatory Ig-superfamily receptors expressed in myeloid and lymphoid cells. Cytokine Growth Factor Rev 11: 209-217, 2000.

26. Yan WH and Fan LA: Residues Met76 and Gln79 in HLA-G alphal domain involve in KIR2DL4 recognition. Cell Res 15: 176-182, 2005.

27. González A, Rebmann V, LeMaoult J, Horn PA, Carosella ED and Alegre E: The immunosuppressive molecule HLA-G and its clinical implications. Crit Rev Clin Lab Sci 49: 63-84, 2012. 
28. Liang S, Ristich V, Arase H, Dausset J, Carosella ED and Horuzsko A: Modulation of dendritic cell differentiation by HLA-G and ILT4 requires the IL-6-STAT3 signaling pathway. Proc Natl Acad Sci USA 105: 8357-8362, 2008.

29. Ketroussi F, Giuliani M, Bahri R, Azzarone B, Charpentier B and Durrbach A: Lymphocyte cell-cycle inhibition by HLA-G is mediated by phosphatase SHP-2 and acts on the mTOR pathway. PLoS One 6: e22776, 2011.

30. LeMaoult J, Zafaranloo K, Le Danff C and Carosella ED: HLA-G up-regulates ILT2, ILT3, ILT4, and KIR2DL4 in antigen presenting cells, NK, cells and T cells. FASEB J 19: 662-664, 2005 .

31. Gooden MJ and van Hall T: Infiltrating CTLs are bothered by HLA-E on tumors. Oncoimmunology 1: 92-93, 2012.

32. LeMaoult J, Krawice-Radanne I, Dausset J and Carosella ED: HLA-G1-expressing antigen-presenting cells induce immunosuppressive CD4+ T cells. Proc Natl Acad Sci USA 101: 7064-7069, 2004.

33. Ibrahim EC, Aractingi S, Allory Y, Borrini F, Dupuy A Duvillard P, Carosella ED, Avril MF and Paul P: Analysis of HLA antigen expression in benign and malignant melanocytic lesions reveals that upregulation of HLA-G expression correlates with malignant transformation, high inflammatory infiltration and HLA-A1 genotype. Int J Cancer 108: 243-250, 2004.

34. Ugurel S, Rebmann V, Ferrone S, Tilgen W, Grosse-Wilde $H$ and Reinhold U: Soluble human leukocyte antigen-G serum level is elevated in melanoma patients and is further increased by interferon-alpha immunotherapy. Cancer 92: 369-376, 2001

35. da Silva GB, Silva TG, Duarte RA, Neto NL, Carrara HH, Donadi EA, Gonçalves MA, Soares EG and Soares CP: Expression of the Classical and Nonclassical HLA molecules in breast cancer. Int J Breast Cancer 2013: 250435, 2013.

36. Elliott RL, Jiang XP, Phillips JT, Barnett BG and Head JF: Human leukocyte antigen $\mathrm{G}$ expression in breast cancer: Role in immunosuppression. Cancer Biother Radiopharm 26: 153-157, 2011.

37. Lefebvre S, Antoine M, Uzan S, McMaster M, Dausset J, Carosella ED and Paul P: Specific activation of the non-classical class I histocompatibility HLA-G antigen and expression of the ILT2 inhibitory receptor in human breast cancer. J Pathol 196: 266-274, 2002

38. Chen HX, Lin A, Shen CJ, Zhen R, Chen BG, Zhang X, Cao FL, Zhang JG and Yan WH: Upregulation of human leukocyte antigen-G expression and its clinical significance in ductal breast cancer. Hum Immunol 71: 892-898, 2010.

39. He X, Dong DD, Yie SM, Yang H, Cao M, Ye SR, Li K, Liu J and Chen J: HLA-G expression in human breast cancer: Implications for diagnosis and prognosis, and effect on allocytotoxic lymphocyte response after hormone treatment in vitro. Ann Surg Oncol 17: 1459-1469, 2010

40. de Kruijf EM, Sajet A, van Nes JG, Natanov R, Putter H, Smit VT, Liefers GJ, van den Elsen PJ, van de Velde CJ and Kuppen PJ: HLA-E and HLA-G expression in classical HLA class I-negative tumors is of prognostic value for clinical outcome of early breast cancer patients. J Immunol 185: 7452-7459, 2010.

41. Ramos CS, Gonçalves AS, Marinho LC, Gomes Avelino MA Saddi VA, Lopes AC, Simões RT and Wastowski IJ: Analysis of HLA-G gene polymorphism and protein expression in invasive breast ductal carcinoma. Hum Immunol 75: 667-672, 2014

42. Sayed D, Badr G, Maximous D, Mikhail NN, Abu-Tarboush F and Alhazza IM: HLA-G and its relation to proliferation index in detection and monitoring breast cancer patients. Tissue Antigens 75: 40-47, 2010.

43. Jeong S, Park S, Park BW, Park Y, Kwon OJ and Kim HS: Human leukocyte antigen-G (HLA-G) polymorphism and expression in breast cancer patients. PLoS One 9: e98284, 2014.

44. Provatopoulou X, Kalogera E, Sagkriotis A, Zagouri F, Nonni A, Zografos GC and Gounaris A: Soluble human leukocyte antigen-G expression in patients with ductal and lobular breas malignancy. Anticancer Res 32: 1021-1026, 2012.

45. Urosevic M, Kurrer MO, Kamarashev J, Mueller B, Weder W, Burg G, Stahel RA, Dummer R and Trojan A: Human leukocyte antigen $G$ up-regulation in lung cancer associates with high-grade histology, human leukocyte antigen class I loss and interleukin-10 production. Am J Pathol 159: 817-824, 2001.

46. Yie SM, Yang H, Ye SR, Li K, Dong DD and Lin XM: Expression of human leucocyte antigen G (HLA-G) is associated with prognosis in non-small cell lung cancer. Lung Cancer 58: 267-274, 2007.
47. Lin A, Zhu CC, Chen HX, Chen BF, Zhang X, Zhang JG, Wang Q Zhou WJ, Hu W, Yang HH, et al: Clinical relevance and functional implications for human leucocyte antigen-g expression in non-small-cell lung cancer. J Cell Mol Med 14: 2318-2329, 2010.

48. Schütt P, Schütt B, Switala M, Bauer S, Stamatis G, Opalka B, Eberhardt W, Schuler M, Horn PA and Rebmann V: Prognostic relevance of soluble human leukocyte antigen- $G$ and total human leukocyte antigen class I molecules in lung cancer patients. Hum Immunol 71: 489-495, 2010.

49. Cao M, Yie SM, Liu J, Ye SR, Xia D and Gao E: Plasma soluble HLA-G is a potential biomarker for diagnosis of colorectal, gastric, esophageal and lung cancer. Tissue Antigens 78: 120-128, 2011.

50. Cai MY, Xu YF, Qiu SJ, Ju MJ, Gao Q, Li YW, Zhang BH, Zhou J and Fan J: Human leukocyte antigen-G protein expression is an unfavorable prognostic predictor of hepatocellular carcinoma following curative resection. Clin Cancer Res 15: 4686-4693, 2009.

51. Lin A, Chen HX, Zhu CC, Zhang X, Xu HH, Zhang JG, Wang Q Zhou WJ and Yan WH: Aberrant human leucocyte antigen-G expression and its clinical relevance in hepatocellular carcinoma. J Cell Mol Med 14: 2162-2171, 2010.

52. Wang Y, Ye Z, Meng XQ and Zheng SS: Expression of HLA-G in patients with hepatocellular carcinoma. Hepatobiliary Pancreat Dis Int 10: 158-163, 2011

53. Park Y, Park Y, Lim HS, Kim YS, Hong DJ and Kim HS: Soluble human leukocyte antigen-G expression in hepatitis B virus infection and hepatocellular carcinoma. Tissue Antigens 79: 97-103, 2012.

54. Fukushima Y, Oshika Y, Nakamura M, Tokunaga T, Hatanaka H, Abe Y, Yamazaki H, Kijima H, Ueyama $\mathrm{Y}$ and Tamaoki N: Increased expression of human histocompatibility leukocyte antigen-G in colorectal cancer cells. Int J Mol Med 2: 349-351, 1998.

55. Ye SR, Yang H, Li K, Dong DD, Lin XM and Yie SM: Human leukocyte antigen $\mathrm{G}$ expression: As a significant prognostic indicator for patients with colorectal cancer. Mod Pathol 20: 375-383, 2007.

56. Zeestraten EC, Reimers MS, Saadatmand S, Goossens-Beumer IJ, Dekker JW, Liefers GJ, van den Elsen PJ, van de Velde CJ and Kuppen PJ: Combined analysis of HLA class I, HLA-E and HLA-G predicts prognosis in colon cancer patients. Br J Cancer 110: 459-468, 2014

57. Guo ZY, Lv YG, Wang L, Shi SJ, Yang F, Zheng GX, Wen WH and Yang AG: Predictive value of HLA-G and HLA-E in the prognosis of colorectal cancer patients. Cell Immunol 293: 10-16, 2015.

58. Zhu CB, Wang CX, Zhang X, Zhang J and Li W: Serum sHLA-G levels: A useful indicator in distinguishing colorectal cancer from benign colorectal diseases. Int J Cancer 128: 617-622, 2011.

59. Yie SM, Yang H, Ye SR, Li K, Dong DD and Lin XM: Expression of human leukocyte antigen G (HLA-G) correlates with poor prognosis in gastric carcinoma. Ann Surg Oncol 14: 2721-2729, 2007.

60. Du L, Xiao X, Wang C, Zhang X, Zheng N, Wang L, Zhang X, Li W, Wang S and Dong Z: Human leukocyte antigen-G is closely associated with tumor immune escape in gastric cancer by increasing local regulatory T cells. Cancer Sci 102: 1272-1280, 2011.

61. Tuncel T, Karagoz B, Haholu A, Ozgun A, Emirzeoglu L, Bilgi O and Kandemir EG: Immunoregulatory function of HLA-G in gastric cancer. Asian Pac J Cancer Prev 14: 7681-7684, 2013.

62. Yie SM, Yang H, Ye SR, Li K, Dong DD and Lin XM: Expression of HLA-G is associated with prognosis in esophageal squamous cell carcinoma. Am J Clin Pathol 128: 1002-1009, 2007.

63. Lin A, Zhang X, Zhou WJ, Ruan YY, Xu DP, Wang Q and Yan WH: Human leukocyte antigen-G expression is associated with a poor prognosis in patients with esophageal squamous cell carcinoma. Int J Cancer 129: 1382-1390, 2011.

64. Hu J, Li L, Liu Y, Chen Y, Liu C, Liang W, Zhao J, Zou H, Cui X, Qi Y, et al: Overexpression of HLA-G Is positively associated with Kazakh esophageal squamous cell carcinoma in Xinjiang, China. Viral Immunol 26: 180-184, 2013.

65. Zheng J, Xu C, Chu D, Zhang X, Li J, Ji G, Hong L, Feng Q, $\mathrm{Li} \mathrm{X}, \mathrm{Wu} \mathrm{G}$, et al: Human leukocyte antigen $\mathrm{G}$ is associated with esophageal squamous cell carcinoma progression and poor prognosis. Immunol Lett 161: 13-19, 2014.

66. Cai MB, Han HQ, Bei JX, Liu CC, Lei JJ, Cui Q, Feng QS, Wang HY, Zhang JX, Liang Y, et al: Expression of human leukocyte antigen $\mathrm{G}$ is associated with prognosis in nasopharyngeal carcinoma. Int J Biol Sci 8: 891-900, 2012. 
67. Silva TG, Crispim JC, Miranda FA, Hassumi MK, de Mello JM, Simões RT, Souto F, Soares EG, Donadi EA and Soares CP: Expression of the nonclassical HLA-G and HLA-E molecules in laryngeal lesions as biomarkers of tumor invasiveness. Histol Histopathol 26: 1487-1497, 2011

68. Gan LH, Huang LF, Zhang X, Lin A, Xu DP, Wang Q, Wang TJ and Yan WH: Tumor-specific upregulation of human leukocyte antigen- $\mathrm{G}$ expression in bladder transitional cell carcinoma. Hum Immunol 71: 899-904, 2010.

69. Ibrahim EC, Guerra N, Lacombe MJ, Angevin E, Chouaib S, Carosella ED, Caignard A and Paul P: Tumor-specific up-regulation of the nonclassical class I HLA-G antigen expression in renal carcinoma. Cancer Res 61: 6838-6845, 2001

70. Kren L, Valkovsky I, Dolezel J, Capak I, Pacik D, Poprach A, Lakomy R, Redova M, Fabian P, Krenova Z and Slaby O: HLA-G and HLA-E specific mRNAs connote opposite prognostic significance in renal cell carcinoma. Diagn Pathol 7: 58, 2012.

71. Ibrahim EC, Allory Y, Commo F, Gattegno B, Callard P and Paul P: Altered pattern of major histocompatibility complex expression in renal carcinoma: Tumor-specific expression of the nonclassical human leukocyte antigen-G molecule is restricted to clear cell carcinoma while up-regulation of other major histocompatibility complex antigens is primarily distributed in all subtypes of renal carcinoma. Am J Pathol 162: 501-508, 2003.

72. Li BL, Lin A, Zhang XJ, Zhang X, Zhang JG, Wang Q, Zhou WJ, Chen HX, Wang TJ and Yan WH: Characterization of HLA-G expression in renal cell carcinoma. Tissue Antigens 74: 213-221, 2009.

73. Li XJ, Zhang X, Lin A, Ruan YY and Yan WH: Human leukocyte antigen-G (HLA-G) expression in cervical cancer lesions is associated with disease progression. Hum Immunol 73: 946-949, 2012.

74. Nunes LM, Ayres FM, Francescantonio IC, Saddi VA, Avelino MA, Alencar Rde C, Silva RC, Meneghini AJ and Wastowski IJ: Association between the HLA-G molecule and lymph node metastasis in papillary thyroid cancer. Hum Immunol 74: 447-451, 2013.

75. de Figueiredo Feitosa NL, Crispim JC, Zanetti BR, Magalhães PK, Soares CP, Soares EG, Neder L, Donadi EA and Maciel LM HLA-G is differentially expressed in thyroid tissues. Thyroid 24: 585-592, 2014.

76. Morandi F, Levreri I, Bocca P, Galleni B, Raffaghello L, Ferrone S, Prigione I and Pistoia V: Human neuroblastoma cells trigger an immunosuppressive program in monocytes by stimulating soluble HLA-G release. Cancer Res 67: 6433-6441, 2007.

77. Morandi F, Scaruffi P, Gallo F, Stigliani S, Moretti S, Bonassi S, Gambini C, Mazzocco K, Fardin P, Haupt R, et al: Bone marrow-infiltrating human neuroblastoma cells express high levels of calprotectin and HLA-G proteins. PLoS One 7: e29922, 2012.

78. Wiendl $\mathrm{H}$, Mitsdoerffer M, Hofmeister V, Wischhusen J, Bornemann A, Meyermann R, Weiss EH, Melms A and Weller M: A functional role of HLA-G expression in human gliomas: An alternative strategy of immune escape. J Immunol 168: 4772-4780, 2002.

79. Kren L, Muckova K, Lzicarova E, Sova M, Vybihal V, Svoboda T, Fadrus P, Smrcka M, Slaby O, Lakomy R, et al: Production of immune-modulatory nonclassical molecules HLA-G and HLA-E by tumor infiltrating ameboid microglia/macrophages in glioblastomas: A role in innate immunity? J Neuroimmunol 220: 131-135, 2010.

80. Kren L, Slaby O, Muckova K, Lzicarova E, Sova M, Vybihal V, Svoboda T, Fadrus P, Lakomy R, Vanhara P, et al: Expression of immune-modulatory molecules HLA-G and HLA-E by tumor cells in glioblastomas: An unexpected prognostic significance? Neuropathology 31: 129-134, 2011.

81. Wastowski IJ, Simões RT, Yaghi L, Donadi EA, Pancoto JT, Poras I, Lechapt-Zalcman E, Bernaudin M, Valable S, Carlotti CG Jr, et al: Human leukocyte antigen- $\mathrm{G}$ is frequently expressed in glioblastoma and may be induced in vitro by combined 5-aza-2'-deoxycytidine and interferon- $\gamma$ treatments: Results from a multicentric study. Am J Pathol 182: 540-552, 2013.

82. Gros F, Sebti Y, de Guibert S, Branger B, Bernard M, Fauchet R and Amiot L: Soluble HLA-G molecules increase during acute leukemia, especially in subtypes affecting monocytic and lymphoid lineages. Neoplasia 8: 223-230, 2006.

83. Dardano A, Rizzo R, Polini A, Stignani M, Tognini S, Pasqualetti G, Ursino S, Colato C, Ferdeghini M, Baricordi OR and Monzani F: Soluble human leukocyte antigen-g and its insertion/deletion polymorphism in papillary thyroid carcinoma: Novel potential biomarkers of disease? J Clin Endocrinol Metab 97: 4080-4086, 2012.
84. Reimers MS, Engels CC, Putter H, Morreau H, Liefers GJ, van de Velde CJ and Kuppen PJ: Prognostic value of HLA class I, HLA-E, HLA-G and Tregs in rectal cancer: A retrospective cohort study. Bmc Cancer 14: 486, 2014.

85. Martelli-Palomino G,PancottoJA,Muniz YC,Mendes-JuniorCT, Castelli EC, Massaro JD, Krawice-Radanne I, Poras I, Rebmann V, Carosella ED, et al: Polymorphic sites at the 3' untranslated region of the HLA-G gene are associated with differential hla-g soluble levels in the Brazilian and French population. PLoS One 8: e71742, 2013.

86. Silva ID, Muniz YC, Sousa MC, Silva KR, Castelli EC, Filho JC, Osta AP, Lima MI and Simões RT: HLA-G 3'UTR polymorphisms in high grade and invasive cervico-vaginal cancer. Hum Immunol 74: 452-458, 2013

87. Jiang Y, Chen S, Jia S, Zhu Z, Gao X, Dong D and Gao Y: Association of HLA-G 3' UTR 14-bp insertion/deletion polymorphism with hepatocellular carcinoma susceptibility in a Chinese population. Dna Cell Biol 30: 1027-1032, 2011.

88. Lau DT, Norris MD, Marshall GM, Haber M and Ashton LJ: HLA-G polymorphisms, genetic susceptibility, and clinical outcome in childhood neuroblastoma. Tissue Antigens 78: 421-427, 2011

89. Ferguson R, Ramanakumar AV, Koushik A, Coutlée F, Franco E and Roger M; Biomarkers of Cervical Cancer Risk Study Team: Human leukocyte antigen $\mathrm{G}$ polymorphism is associated with an increased risk of invasive cancer of the uterine cervix. Int $\mathbf{J}$ Cancer 131: E312-E319, 2012

90. Ghandri N, Gabbouj S, Farhat K, Bouaouina N, Abdelaziz H, Nouri A, Chouchane L and Hassen E: Association of HLA-G polymorphisms with nasopharyngeal carcinoma risk and clinical outcome. Hum Immunol 72: 150-158, 2011.

91. Xu HH, Shi WW, Lin A and Yan WH: HLA-G 3' untranslated region polymorphisms influence the susceptibility for human papillomavirus infection. Tissue Antigens 84: 216-222, 2014.

92.Eskandari-Nasab E, Hashemi M, Hasani SS, Omrani M, Taheri $M$ and Mashhadi MA: Association between HLA-G 3'UTR 14-bp ins/del polymorphism and susceptibility to breast cancer. Cancer Biomark 13: 253-259, 2013.

93. Rolfsen GB, Castelli EC, Donadi EA, Duarte RA and Soares CP HLA-G polymorphism and breast cancer. Int J Immunogenet 41: 143-148, 2014.

94. Teixeira AC, Mendes-Junior CT, Souza FF, Marano LA, Deghaide NH, Ferreira SC, Mente ED, Sankarankutty AK, Elias-Junior J, Castro-e-Silva O, et al: The 14bp-deletion allele in the HLA-G gene confers susceptibility to the development of hepatocellular carcinoma in the Brazilian population. Tissue Antigens 81: 408-413, 2013.

95. Kim SK, Chung JH, Jeon JW, Park JJ, Cha JM, Joo KR, Lee JI and Shin HP: Association between HLA-G 14-bp insertion/deletion polymorphism and hepatocellular carcinoma in Korean patients with chronic hepatitis B viral infection. Hepatogastroenterology 60: 796-798, 2013.

96. Yan WH: HLA-G expression in cancers: Potential role in diagnosis, prognosis and therapy. Endocr Metab Immune Disord Drug Targets 11: 76-89, 2011.

97. Teng MW, Galon J, Fridman WH and Smyth MJ: From mice to humans: Developments in cancer immunoediting. J Clin Invest 125: 3338-3346, 2015.

98. Kochan G, Escors D, Breckpot K and Guerrero-Setas D: Role of non-classical MHC class I molecules in cancer immunosuppression. Oncoimmunology 2: e26491, 2013.

99. Zeng XC, Zhang T, Huang DH, Wang GY, Chen W, Li H, Zhang J, Fang TL, Zhang Q and Chen GH: RNA interfering targeting human leukocyte antigen-G enhanced immune surveillance mediated by the natural killer cells on hepatocellular carcinoma. Ann Clin Lab Sci 43: 135-144, 2013.

100. Lin A, Xu HH, Xu DP, Zhang X, Wang Q and Yan WH: Multiple steps of HLA-G in ovarian carcinoma metastasis: Alter NK cytotoxicity and induce matrix metalloproteinase-15 (MMP-15) expression. Hum Immunol 74: 439-446, 2013.

101. Lesport E, Baudhuin J, LeMaoult J, Sousa S, Doliger C, Carosella ED and Favier B: Human melanoma cell secreting human leukocyte antigen-G5 inhibit natural killer cell cytotoxicity by impairing lytic granules polarization toward target cell. Hum Immunol 70: 1000-1005, 2009.

102. Moreau P, Mouillot G, Rousseau P, Marcou C, Dausset J and Carosella ED: HLA-G gene repression is reversed by demethylation. Proc Natl Acad Sci USA 100: 1191-1196, 2003. 
103. Zidi I, Guillard C, Marcou C, Krawice-Radanne I, Sangrouber D, Rouas-Freiss N, Carosella ED and Moreau P: Increase in HLA-G1 proteolytic shedding by tumor cells: A regulatory pathway controlled by NF-kappaB inducers. Cell Mol Life Sci 63: 2669-2681, 2006.

104. Rodríguez JA, Galeano L, Palacios DM, Gómez C, Serrano ML, Bravo MM and Combita AL: Altered HLA class I and HLA-G expression is associated with IL-10 expression in patients with cervical cancer. Pathobiology 79: 72-83, 2012.

105. Tao S, He H, Chen Q and Yue W: GPER mediated estradiol reduces miR-148a to promote HLA-G expression in breast cancer. Biochem Biophys Res Commun 451: 74-78, 2014.

106. Caumartin J, Favier B, Daouya M, Guillard C, Moreau P, Carosella ED and LeMaoult J: Trogocytosis-based generation of suppressive NK cells. Embo J 26: 1423-1433, 2007.

107. LeMaoult J, Caumartin J, Daouya M, Favier B, Le Rond S, Gonzalez A and Carosella ED: Immune regulation by pretenders: Cell-to-cell transfers of HLA-G make effector T cells act as regulatory cells. Blood 109: 2040-2048, 2007.

108. Brown R, Kabani K, Favaloro J, Yang S, Ho PJ, Gibson J, Fromm P, Suen H, Woodland N, Nassif N, et al: CD86+ or HLA-G+ can be transferred via trogocytosis from myeloma cells to $\mathrm{T}$ cells and are associated with poor prognosis. Blood 120: 2055-2063, 2012

109. Morandi F, Ferretti E, Bocca P, Prigione I, Raffaghello L and Pistoia V: A novel mechanism of soluble HLA-G mediated immune modulation: Downregulation of $\mathrm{T}$ cell chemokine receptor expression and impairment of chemotaxis. PLoS One 5: e11763, 2010.

110. Morandi F, Ferretti E, Castriconi R, Dondero A, Petretto A, Bottino C and Pistoia V: Soluble HLA-G dampens CD94/NKG2A expression and function and differentially modulates chemotaxis and cytokine and chemokine secretion in CD56bright and CD56dim NK cells. Blood 118: 5840-5850, 2011.
111. Naji A, Menier C, Morandi F, Agaugué S, Maki G, Ferretti E, Bruel S, Pistoia V, Carosella ED and Rouas-Freiss N: Binding of HLA-G to ITIM-bearing Ig-like transcript 2 receptor suppresses B cell responses. J Immunol 192: 1536-1546, 2014.

112. Liu X, Gu W and Li X: HLA-G regulates the invasive properties of JEG-3 choriocarcinoma cells by controlling STAT3 activation. Placenta 34: 1044-1052, 2013.

113. Liang S, Baibakov B and Horuzsko A: HLA-G inhibits the functions of murine dendritic cells via the PIR-B immune inhibitory receptor. Eur J Immunol 32: 2418-2426, 2002.

114. Agaugué S, Carosella ED and Rouas-Freiss N: Role of HLA-G in tumor escape through expansion of myeloid-derived suppressor cells and cytokinic balance in favor of Th2 versus Th1/Th17. Blood 117: 7021-7031, 2011.

115. Loumagne L, Baudhuin J, Favier B, Montespan F, Carosella ED and Rouas-Freiss N: In vivo evidence that secretion of HLA-G by immunogenic tumor cells allows their evasion from immunosurveillance. Int J Cancer 135: 2107-2117, 2014.

116. Dong DD, Yie SM, Li K, Li F, Xu Y, Xu G, Song L and Yang H: Importance of HLA-G expression and tumor infiltrating lymphocytes in molecular subtypes of breast cancer. Hum Immunol 73: 998-1004, 2012.

117. Gallegos CE, Michelin S, Trasci SB, Lobos EA, Dubner D and Carosella ED: HLA-G1 increases the radiosensitivity of human tumoral cells. Cell Immunol 287: 106-111, 2014.

(i) (3) This work is licensed under a Creative Commons Attribution-NonCommercial-NoDerivatives 4.0 International (CC BY-NC-ND 4.0) License. 